\title{
PENGARUH PERBANDINGAN KONSTRUKSI STATOR TERHADAP TEGANGAN KELUARAN GENERATOR LINIER
}

\author{
Hasyim Asyari, Bana Handaga, Abdul Basith, Muh Aziz Himawan \\ Teknik Elektro, Fakultas Teknik, Universitas Muhammadiyah Surakarta \\ Jl. A. Yani Tromol Pos 1 Pabelan, Kartasura, Surakarta \\ Hasyim.Asyari@ums.ac.id
}

\begin{abstract}
Abstraksi
Kondisi dengan banyak pulau ini merupakan kondisi yang menjadimasalah unik bagi pemerataan listrik sekaligus tantangan bagi PLN. Maka dari itu butuh sesuatu pembaruan dalam sistem pembangkit tenaga listrik yang lebih praktis, efisien, dan juga mudah dalam perawatan serta dapat digunakan untuk pulau pulau yang terpencil di indonesia. Generator adalah suatu mesin yang digerakkan secara mekanis oleh penggerak mula misalnya turbin uap, turbin hidrolik, atau mesin disel dan menghasilkan energi untuk lampu listrik atau mesin-mesin yang lain. Penelitian ini bertujuan untuk mengetahui perbandingan desian stator tipe radial dengan desain stator tipe linier. Kemudian membahas tentang pembuatan generator liner dan juga perbandingan 3 buah stator yang berbeda jumlah lilitan, celah udara, serta desainnya. Penelitian ini menggunakan jenis lilitan yang berbeda yaitu lilitan berdiameter 0,8 dan $0,4 \mathrm{~mm}$.Pada stator 1 menggunakan lilitan berdiameter 0,8 jumlah lilitannya 70 lilitan, dapat menghasilkan tegangan keluaran $160 \mathrm{mV}$ pada kecepatan $200 \mathrm{Rpm}$. Kemudian pada $450 \mathrm{Rpm}$ menghasilkan tegangan maksimal $550 \mathrm{mV}$. Pada stator ke 2 menggunakan lilitan berdiameter 0,4 dengan jumlah lilitan 200 lilitan, dapat menghasilkan tegangan $134 \mathrm{mV}$ pda kecepatan $200 \mathrm{Rpm}$. Kemudian pada kecepatan $450 \mathrm{Rpm}$ menghasilkan $560 \mathrm{mV}$. Pada stator ke 3 mengunakan lilitan 0,4 mm dengan jumlah lilitan 200 lilitan, dapat menghasilkan tegangan keluaran $2 \mathrm{~V}$ pada kecepatan $200 \mathrm{Rpm}$. Kemudian pada kecepatan 500 Rpm menghasilkan 3,3 V tegangan keluaran.
\end{abstract}

Kata Kunci: Generator Linier, Energi Terbarukan, Magnet Permanen

\begin{abstract}
The conditions with much of the island is a condition that becomes a unique problem and electricity equalization supply challenges for PLN. Therefore it is needed the enhancement in the power system that is more practical, efficient, and easy to maintenance and can be used for remote islands in Indonesia. Generator is a machine that is driven mechanically by the prime movers eg steam turbines, hydraulic turbines or diesel engines and produce energy to power lights or other machines. This study aimed to compare the stator design of radial type and linear-type. Furthermore, It is also addresses the manufacture of generators liner and also do comparison of three different pieces of stator winding amount, the air gap, as well as design. This study used different types of windings, namely winding diameter of 0.8 and $0.4 \mathrm{~mm}$. In the stator 1 using coil diameter of 0.8 with the number of windings 70 windings, then resulted output voltage of $160 \mathrm{mV}$ at a speed of $200 \mathrm{rpm}$. Then at $450 \mathrm{rpm}$ produces a maximum voltage of $550 \mathrm{mV}$. In the stator windings to 2 using 0.4 in diameter by the number of coil windings 200 , then produced $134 \mathrm{mV}$ voltage pda speed of $200 \mathrm{rpm}$. Then, at a speed of $450 \mathrm{rpm}$ produces $560 \mathrm{mV}$. In the stator windings using 0.4 to $3 \mathrm{~mm}$ by the number of coil windings 200, can produce output voltage of 2 $\mathrm{V}$ at a speed of $200 \mathrm{rpm}$. Then, at a speed of $500 \mathrm{rpm}$ to produce a $3.3 \mathrm{~V}$ output voltage.
\end{abstract}

Keywords: Linier Generator, Renewable Energy, Permanent Magnet 


\section{PENDAHULUAN}

Energi listrik merupakan salah satu kebutuhan pokok yang sangat penting dalam kehidupan manusia saat ini, dimana hampir semua aktifitas manusia berhubungan dengan energi listrik. Seiring dengan pertumbuhan ekonomi dan tingkat populasi penduduk di Indonesia yang semakin tinggi maka permintaan akan energi listrik juga meningkat. Oleh karena itu berbagai upaya yang dilakukan oleh pemerintah agar dapat memenuhi kebutuhan listrik masyarakat. Saat ini ketersediaan sumber tenaga listrik belum mampu memenuhi kebutuhan listrik di indonesia. Terjadinya pemutusan sementara dan pembagian aliran listrik ini merupakan dampak dari terbatasnya sumber listrik yang disupply oleh PLN. Hal ini terjadi karena laju pertambahan energi terbarukan serta pengadaan pembangkit energi listrik yang tidak sebanding dengan penigkatan konsumsi listrik. Mulai bulan Agustus 2006, PLN APJ Surakarta akan melakukan pemadaman listrik secara begilir dengan alasan PLTA pendukungnya tidak mampu menyuplai pasokan listrik akibat kemarau. Sedangkan jika mengandalkan pembangkit tenaga batu bara, gas maupun BBM sering terkendala keterlambatan suplai.Alasan lainnya adalah karena APJ PLN Surakarta secara resmi mengalami penurunan pasokan daya listrik sesuai rapat manager APJ PLN se Jawa dan Bali di Kudus pada 27 Juli lalu yang memutuskan pasokan listrik ke APJ Surakarta diturunkan 16 persen dari kebutuhan, atau 64 MW dari 400 MW kebutuhan listrik (www.Detik.com).

Salah satu komponen utama yang menjadi pertimbangan dalam perencanaan sistem pembangkit adalah jenis generator yang digunakan untuk mengubah energi mekanis menjadi energi listrik. Generator adalah suatu mesin yang digerakkan secara mekanis oleh penggerak mula misalnya turbin uap, turbin hidrolik, atau mesin disel dan menghasilkan energi untuk lampu listrik atau mesin-mesin yang lain. Kontruksi generator terdiri dari komponen stator, komponen rotor, komponen pendingin, komponen sistem eksitasi statis dan Insulated Phase Busduct (IPB). Generator linier adalah salah satu alat yang biasanya digunakan di laut, yang mengubah energi gelombang laut menjadi energi listrik. Tegangan listrik yang dihasilkan pada generator linier ini masih berupa AC berupa pulsa-pulsa tegangan, sehingga bila langsung digunakan untuk menyalakan lampu, maka akan berkedip-kedip. Untuk mensetabilkan keluaran tesebut maka arus akan diubah ke DC, kemudian arus dikumpulkan ke dalam sebuah kapasitor. Sehingga arus yang dihasilkan lebih stabil (DAFTAR PUSTAKA 1998-2010).

Pada penelitian sebelumnya yang terkait dengan magnet permannent, menunjukan bahwa magnet permannent dapat digunakan sebagai energi sumber. Konversi energi magnet permannent telah dilakukan, yaitu Parendev Permanent Magnet Motor (PPMM). Sesuai dengan namanya, mesin ini energi rotasi mekanik yang berasal dari magnet permannent (Andi Pawawoi, 2014).

Medan magnet yang kuat sangat penting untuk pengaplikasian medan magnet intensitas tinggi. Medan magnet harus terkosentrasi di pusat rumah medan magnet, dimana disana terdapat coil yang telah di susun (Krishna Manasa Rao, 2013)

Generator induksi menjadi lebih efisien untuk penerapan energi terbarukan. Beberapa keuntungan dari generator induksi seperti tidak adanya sumber DC yang terpisah untuk eksitasinya, perlindungan dari overload serta tidak mudah untuk konsleting. Tetapi generator induksi mempunyai kekurangan yaitu keluaran tegangan yang kecil. Oleh karena itu di gunakan PMIG (Permanent-magnet induction generator) untuk meningkatkan faktor daya, tegangan relegasi dan efisiensi. PMIG, permanent magnet tergabung dengan rotor dari generator tersebut (PAWAN SHARMA, 2011).

Linear generator dapat mengatasi kelemahan dari generator yang menggunakan gerakan rotasi, karena dapat langsung menggunakan gerakan kinetik linear tanpa melalui mekanisme mekanik untuk konversi pergerakannya.( Sang-Shin Park, 2013)

Penelitian ini membahas tentang bagaimana membuat prototype generator linier. Kemudaian mebandingkan rancangan 3 stator yang berbeda dari segi desain, jumlah lilitan, 
maupun keluaran nanti yang dikeluarkan. Pada dasarnya generator linier sama seperti generator jenis radial, yang membedakan hanya desain rotor yang di ubah menjadi linier/ gerakannya maju mundur.

Rotor adalah bagian pengerak dari sebuah generator. Dalam penelitian ini rotor di ubah menjadi desain linier dengan panjang $64 \mathrm{~cm}$. Mengunakan magnet permanent sebanyak 10 buah yang dirangkai secara $\mathrm{N}-\mathrm{S}, \mathrm{N}-\mathrm{S}$.
Stator adalah bagian yang diam pada generator yang berfungsi untuk menangkap medan magnet yang ditimbulkan oleh rotor. Sehingga menpung medan magnet yang terinduksi kemudian mengeluarkan berupa keluaran tegangan maupun arus.

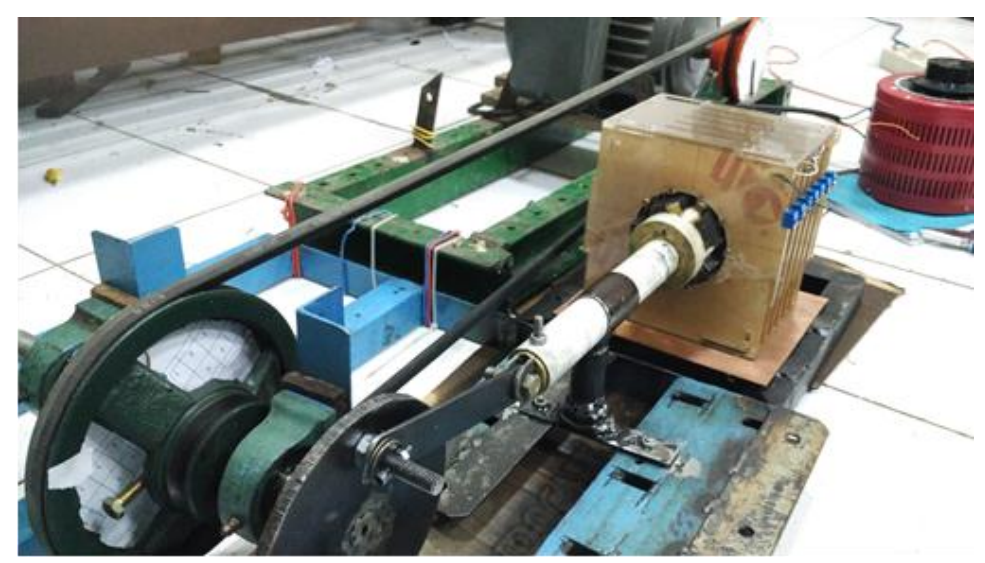

Gambar 1. Generator linier

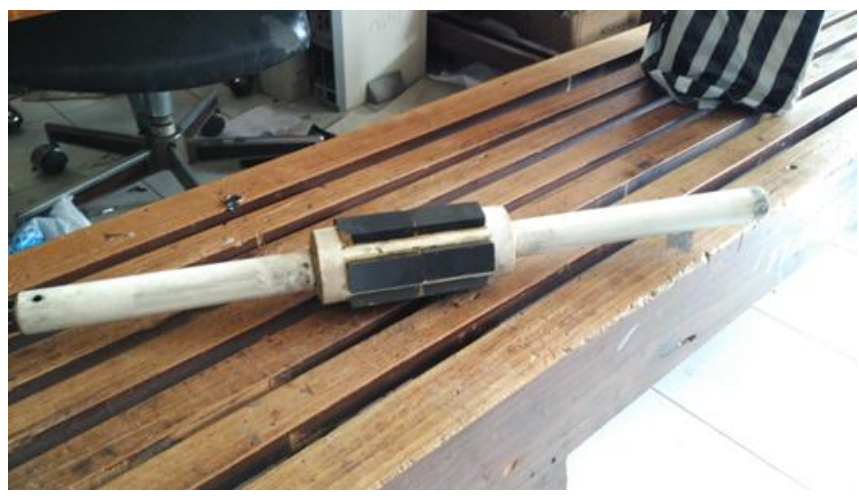

Gambar 2. Rotor Generator Magnet Permanen

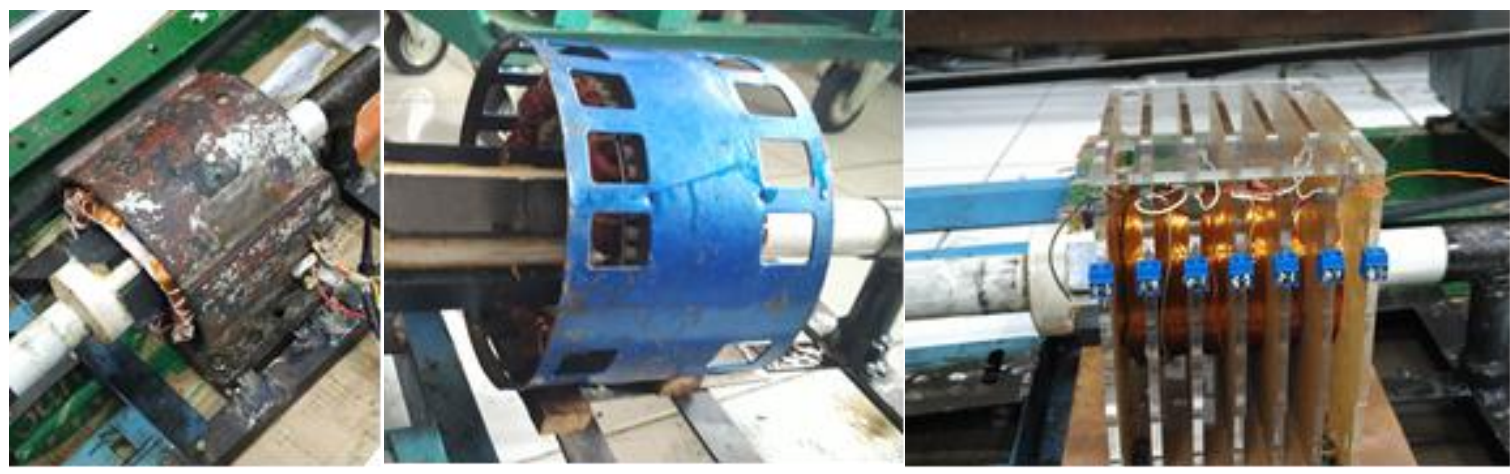

Gambar 3. Desain Stator Generator Magnet Permanen 


\section{METODE}

Studi literatur dilakukan dengan mengumpulkan data yang berkaitan dengan penelitian yang akan dilakukan. Data yang dikumpulkan berupa buku, jurnal ilmiah, karya-karya ilmiah, media cetak maupun elektronik (internet) yang nantinya digunakan sebagai acuan dalam penelitian.

Rancang bangun alat dilakukan mempersiapkan peralatan dan bahan yang diperlukan untuk membuat generator linear. Dalam penelitian ini pembuatan alat dilakukan dengan membuat terlebih dahulu sebuah generator linear yang kemudian akan di analisa hasil keluaran tegangan serta perbandingan 3 stator yang berbeda jumlah lilitan maupun desainnya.

Pengujian alat dilakukan untuk mengetahui hasil dari alat yang telah dibuat. Dalam pengujian membandingkan hasil yang didapat dari penelitian dengan tujuan yang ingin dicapai.Untuk pengukuran kecepatan, ini di ukur dari puli motor yang terhubung melalui belt ke puli generator linier. Yang perbandingan besar puli nya adalah $1: 2$, puli di motor lebih kecil di bandingkan puli di generator linier. Pengujian alat dilakukan dari kecepatan 200-500 Rpm.

Analisa data dilakukan dengan mengumpulkan data yang diperoleh dari pengujian untuk dibandingkan dengan data yang diperoleh dari studi literatur. Data yang dianalisa dalam penelitian ini yaitu keluaran dari generator linier serta perbandingan 3 sdesain setator yang berbeda.

Diagram alir penelitian (flowchart) difungsikan untuk mengetahui tahapan yang dilakukan penulis dalam penelitian ini. Gambar flowchart ditunjukkan pada gambar 4.

\section{HASIL DAN PEMBAHASAN}

3.1 Percobaan mengunakan desain stator generator radial 70 lilitan

Pada penelitian ini menggunakan sebuah stator generator radial 1 fasa. Generator ini memiliki 70 lilitan, dengan celah udara antara magnet dan belitan sebesar $1 \mathrm{~cm}$. Diameter kawat penghantar (belitan) sebesar 0,8 mm. 


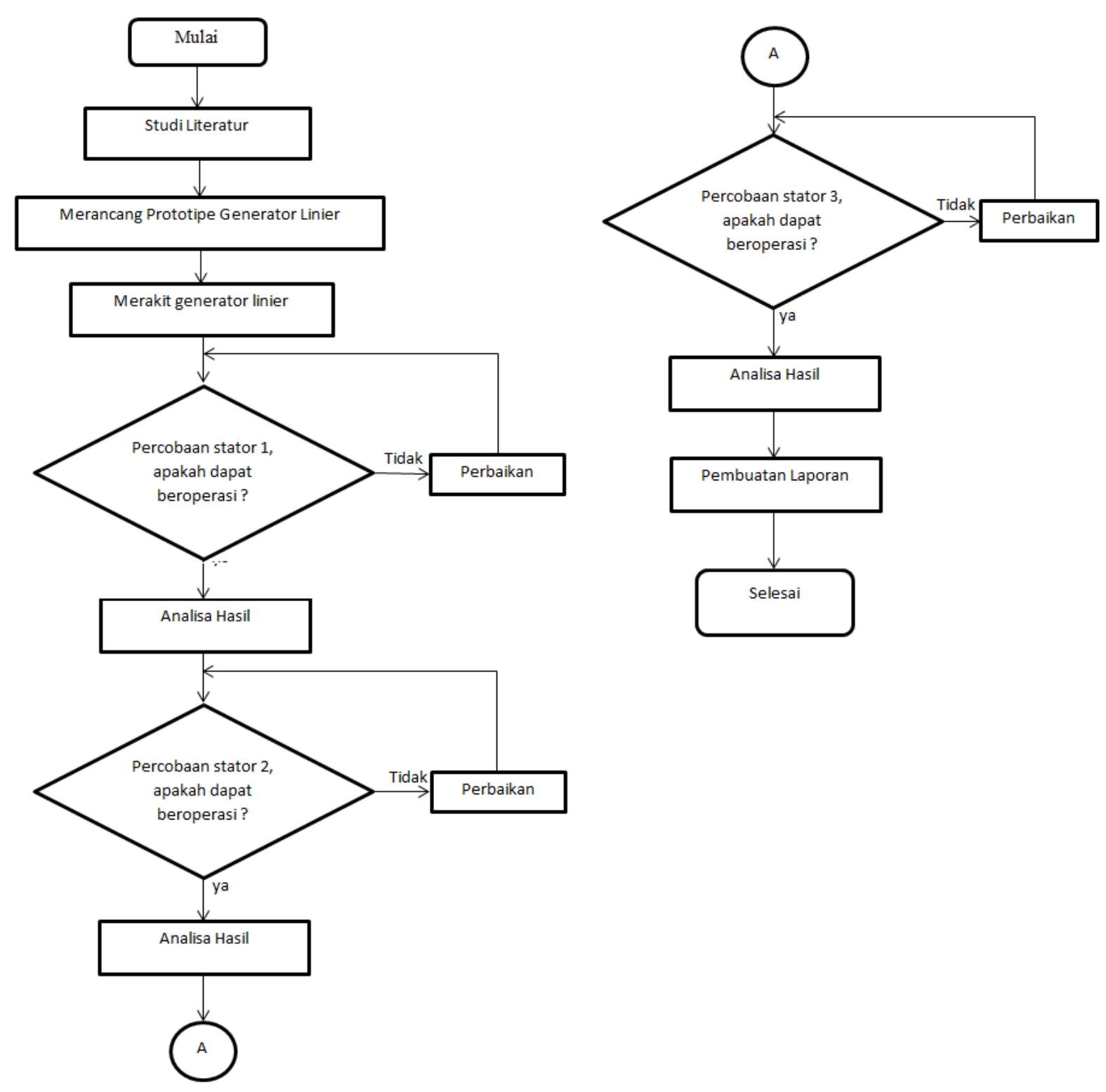

Gambar 4. Flowchart Penelitian

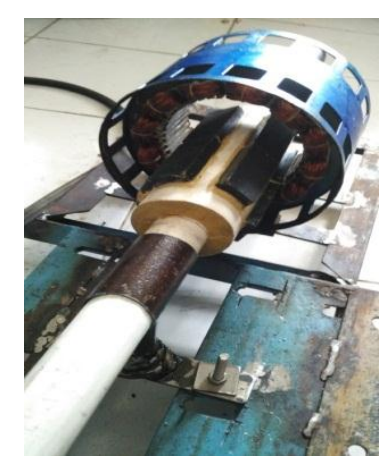

Gambar 5. Percobaan 1 Desain Stator Radial 1 fasa 70 lilitan 


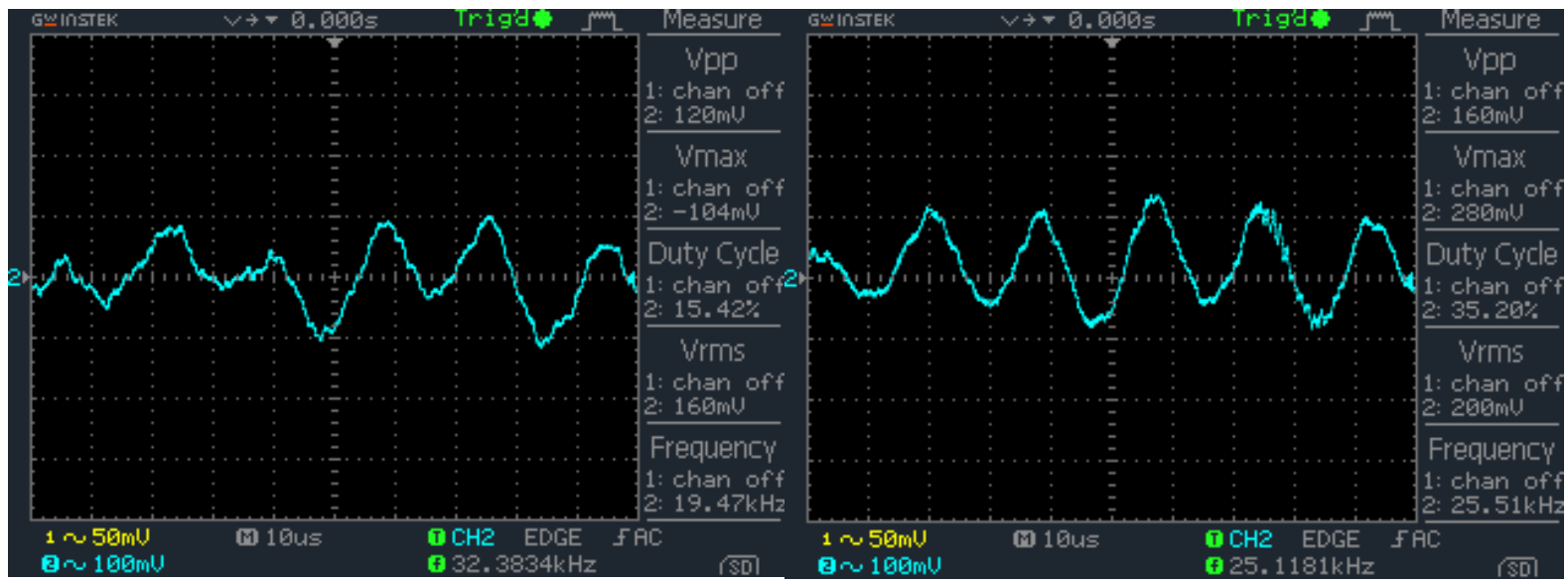

Gambar 6. Hasil Pengukuran dengan Osiloskop

Pada gambar 6 ini menunjukan tegangan kemudian gambar $\mathrm{B}$ tegangan yang di dan bentuk gelombang yang di keluarkan oleh bangkitkan sebesar $200 \mathrm{mV}$. Bentuk stator radial 70 lilitan. Gambar A menunjukan gelombangnya cenderung tidak stabil. tegangan yang di bangkitkan sebesar $160 \mathrm{mV}$,

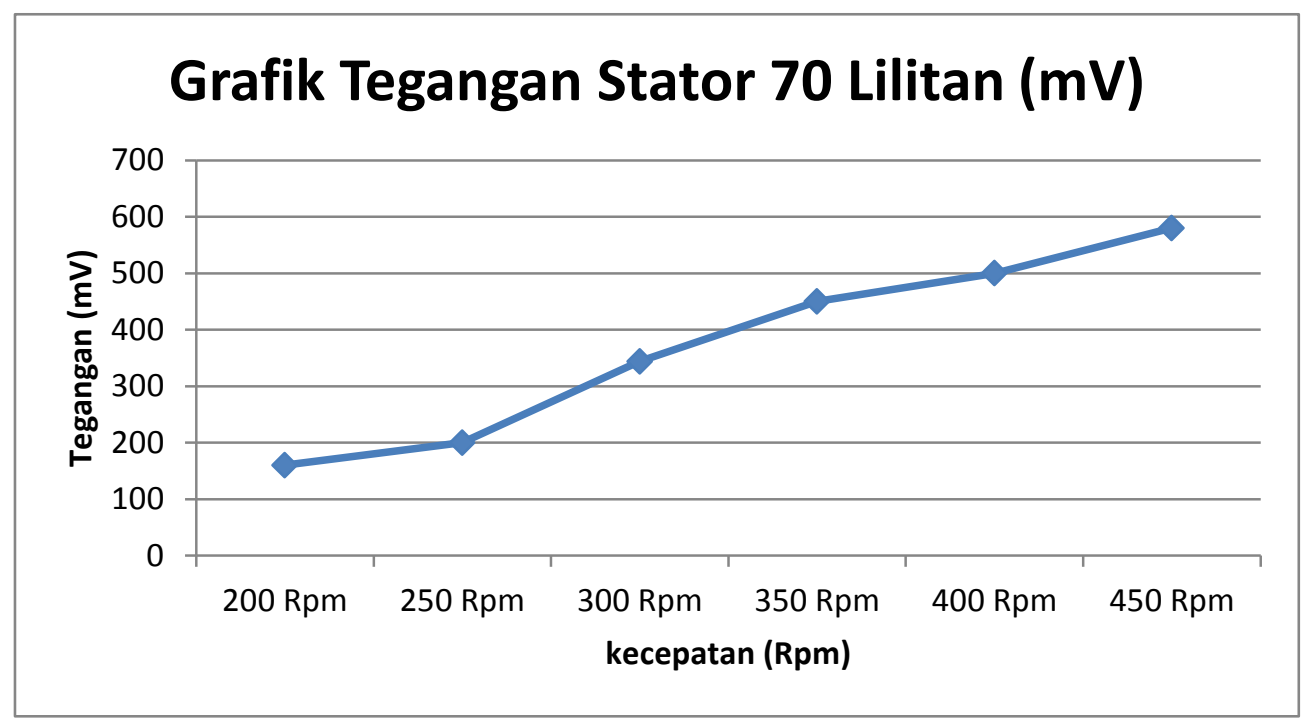

Gambar 7. Grafik Percobaan 1

Pada gambar 7 menunjukan data-data yang telah di ambil selama 6 kali percobaan. Dari $200 \mathrm{Rpm}$ menghasilkan tegangan $160 \mathrm{mV}$, ketika kecepatan ditambah mengalami peningkatan tegangan sampai pada kecepatan maksimal $450 \mathrm{Rpm}$ menghasilkan $580 \mathrm{mV}$. Kecepatan ini merupakan kecepatan dari motor.

Secara konsep stator ini sudah dapat mengeluarkan tegangan, walaupun masih kecil. Hal ini dikarena desain ini untuk generator tipe radial (berputar), sedangkan pada percobaan ini menggunakan rotor yang gerakkanya linier.
3.2 Percobaan menggunakan stator generator radial 200 lilitan

Pada penelitian ini menggunakan desain stator generator radial 3 fasa. Generator ini memiliki 200 lilitan dengan celah udara $0,5 \mathrm{~cm}$. Bentuk stator pada percobaan ini di tunjukan pada gambar 8.Percobaan kali kedua ini, sedikit berbeda karena menggunakan desian lilitan 3 fasa dan juga penambahan lilitan menjadi 200 lilitan. Akan tetapi pada percobaan ini tetap mengambil tegangan keluaran pada salah satu fasanya saja. 


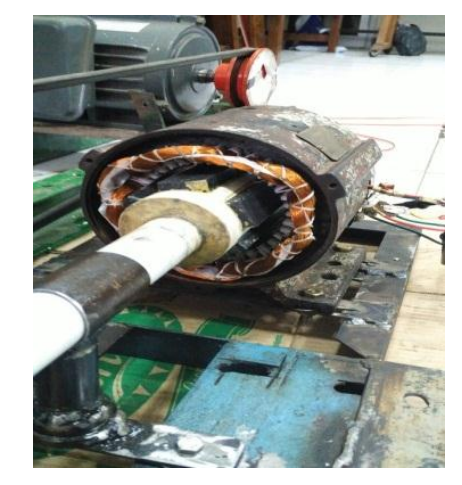

Gambar 8. Percobaan 2 Desain Stator 3 fasa 200 lilitan
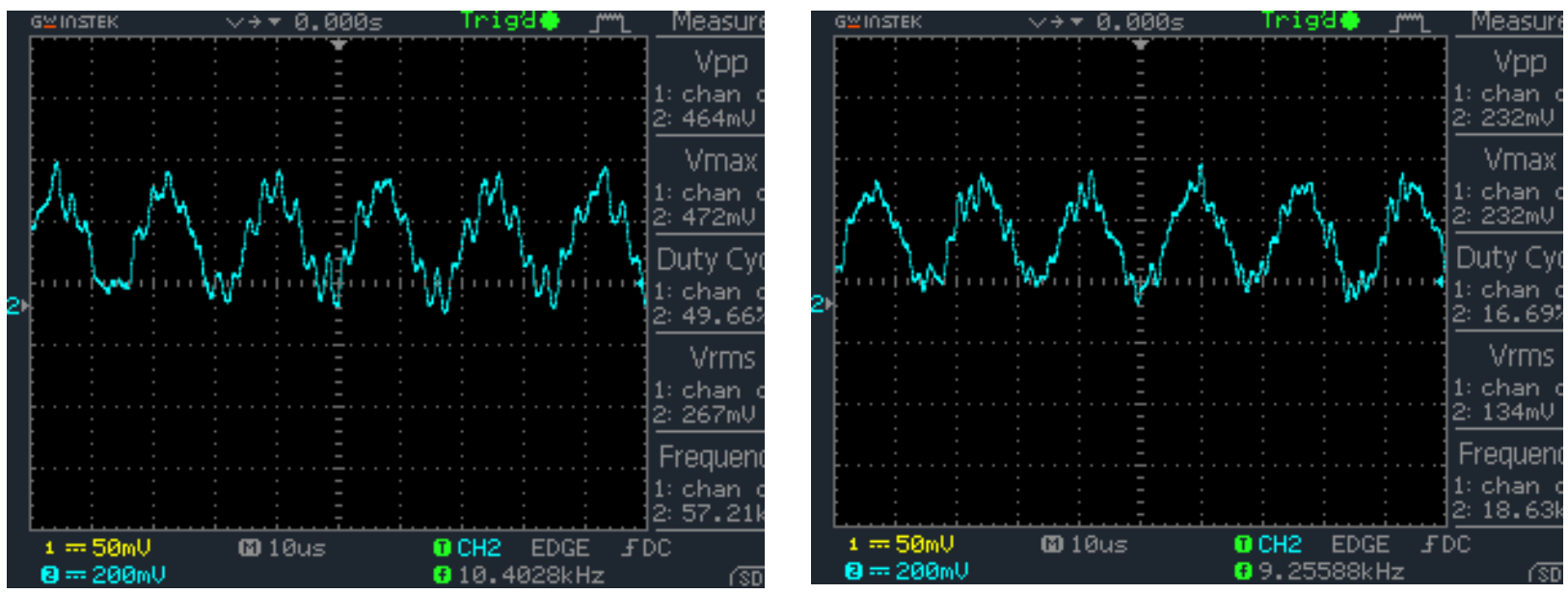

Gambar 9. Hasil Pengukuran dengan Osiloskop

Pada gambar 9 ini menunjukan hasil sama tidak setabil, tetapi pada percobaan ini percobaan kedua. Tegangan keluaran sebesar bentuk gelombang cenderung menurun atau $134 \mathrm{mv}$ dan $267 \mathrm{mV}$. Bentuk gelombang masih semakin tidak stabil.

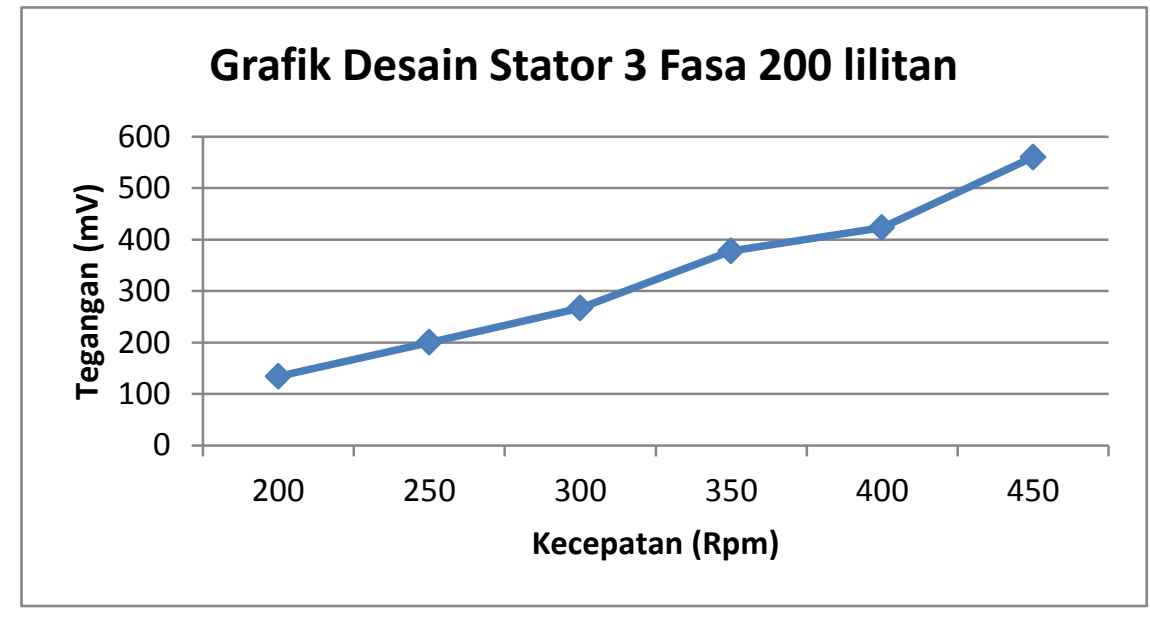

Gambar 10. Grafik Percobaan 2 
Gambar 10 menunjukan hasil percobaan dari $200 \mathrm{Rpm}$ menghasilkan tegangan keluaran $134 \mathrm{mV}$, ketika kecepatan ditambah mengalami kenaikan tegangan sampai pada kecepatan maksimal $450 \mathrm{Rpm}$, menghasilkan tegangan keluaran $560 \mathrm{mV}$.

Pada hasil kali ini ada penurunan tegangan yang terjadi antara percobaan 1 dan 2. Banyak faktor yang mempengaruhi salah satunya, perbedaan besar diameter belitan percobaan 1 yaitu $0,8 \mathrm{~mm}$ sedangkan pada percobaan 2 menggunakan besar diameter lilitan 0,4. Secara teori ketika semakin besar diameter lilitan maka kapasitas medan magnet yang di tangkap semakin besar.

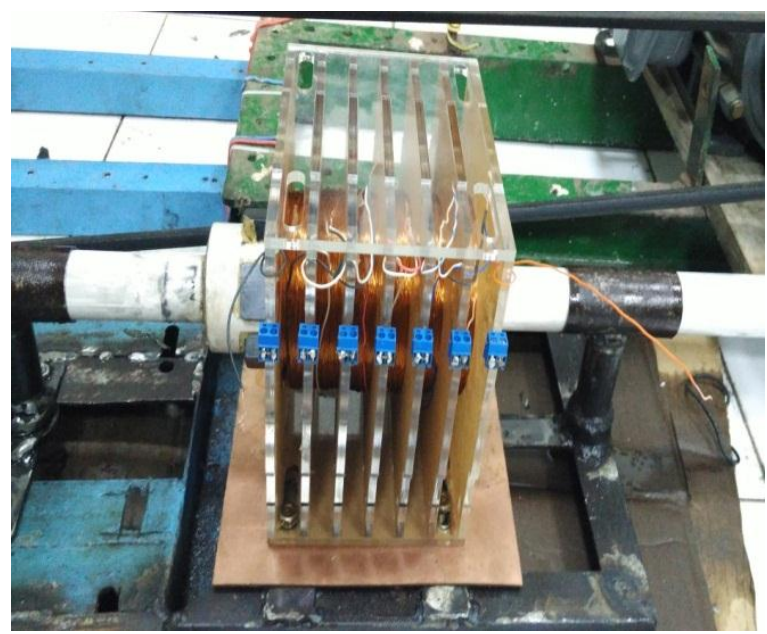

Secara konsep desain stator generator ini masih sama dengan percobaan 1 yang keluaran tegangannya masih kecil. Di karenakan desain belitan yang tidak cocok dengan gerakan rotor (linier).

3.3 Percobaan menggunakan desain stator generator linier 200 lilitan.

Percobaan yang ketiga ini menggunakan desain setator generator linier. Stator ini di desain untuk memaksimalkan perpotongan medan magnet yang terjadi. Sehingga induksi yang di hasilkan bisa maksimal. Stator ini mempunyai 6 wadah belitan, di setiap 1 wadah belitan mempunyai jumlah lilitan sebesar 200 lilitan. Dan di rangkai secara bolak balik lilitannya.

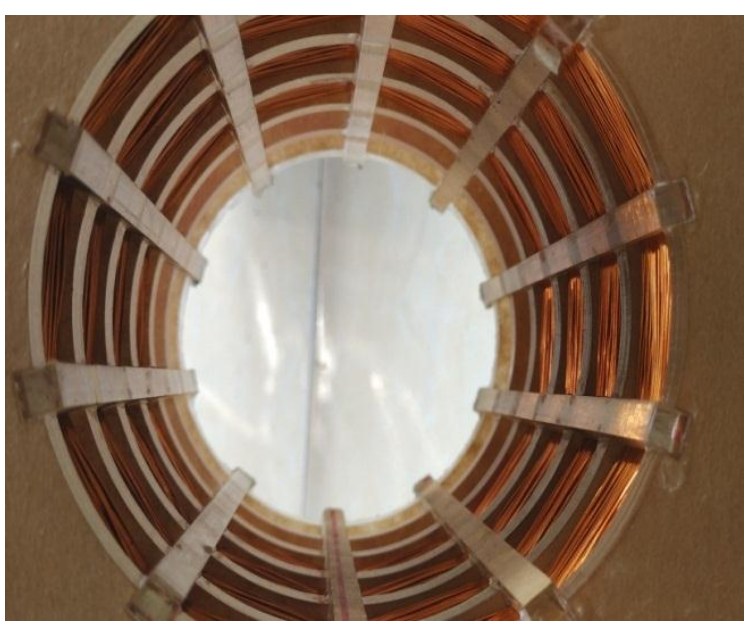

Gambar 11. Desain Stator Generator Linier

Pada desain ini menggunakan kawat belitan yang berdiameter $0,4 \mathrm{~mm}$. Jarak antara belitan dan magnet sebesar $0,5 \mathrm{~cm}$. Dengan ukuran desain 175x175mm, diameter lubang (tempat belitan) $90 \mathrm{~mm}$. Bahan yang di gunakan yaitu akrilik, yang tidak menghantarkan magnet.

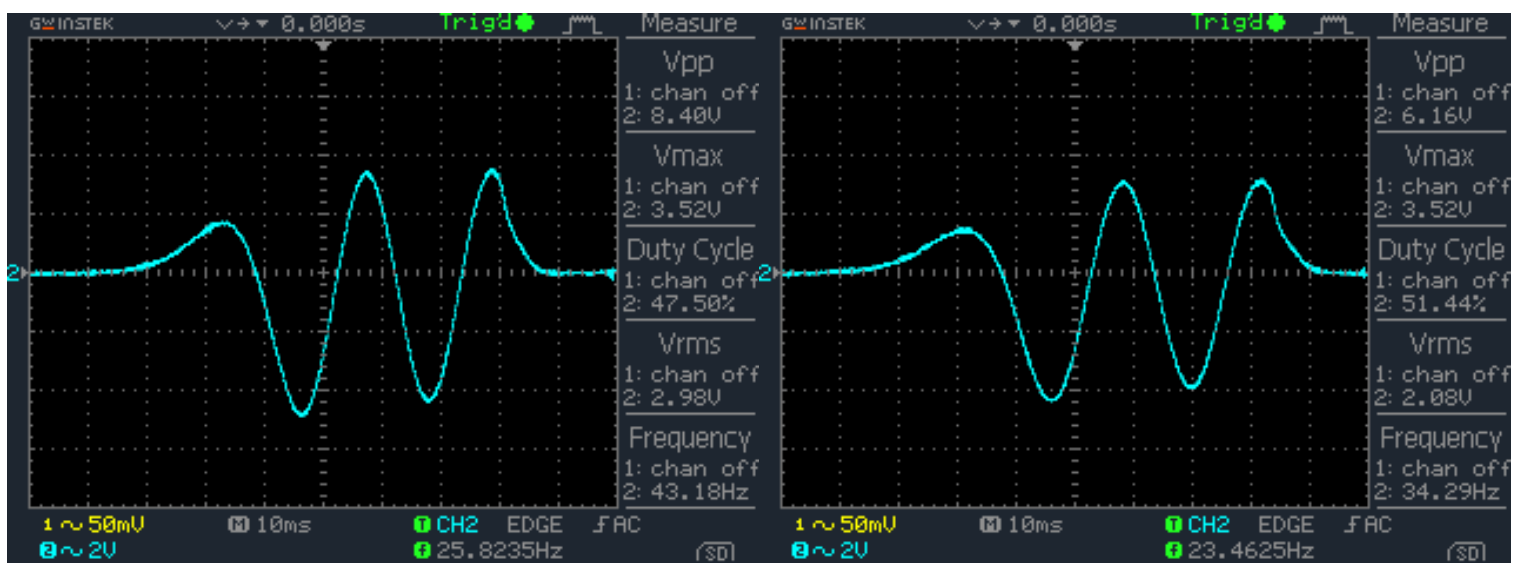

Gambar 12. Bentuk Gelombang menggunakan Osiloskop 
Percobaan ketiga ini, pengukuran tegangan keluaran menggunakan multi-meter analog. Untuk Osiloskop hanya untuk melihat bentuk dari gelombang pada percobaan ini. Bentuk gelombang pada percobaan kali ini lebih stabil.
Yang dilihat pada gambar diatas. Di karenakan desain maupun perpotongan medan magnet yang cocok/benar, sehingga induksi magnetik terjadi secara terus-menerus (tidak hilang).

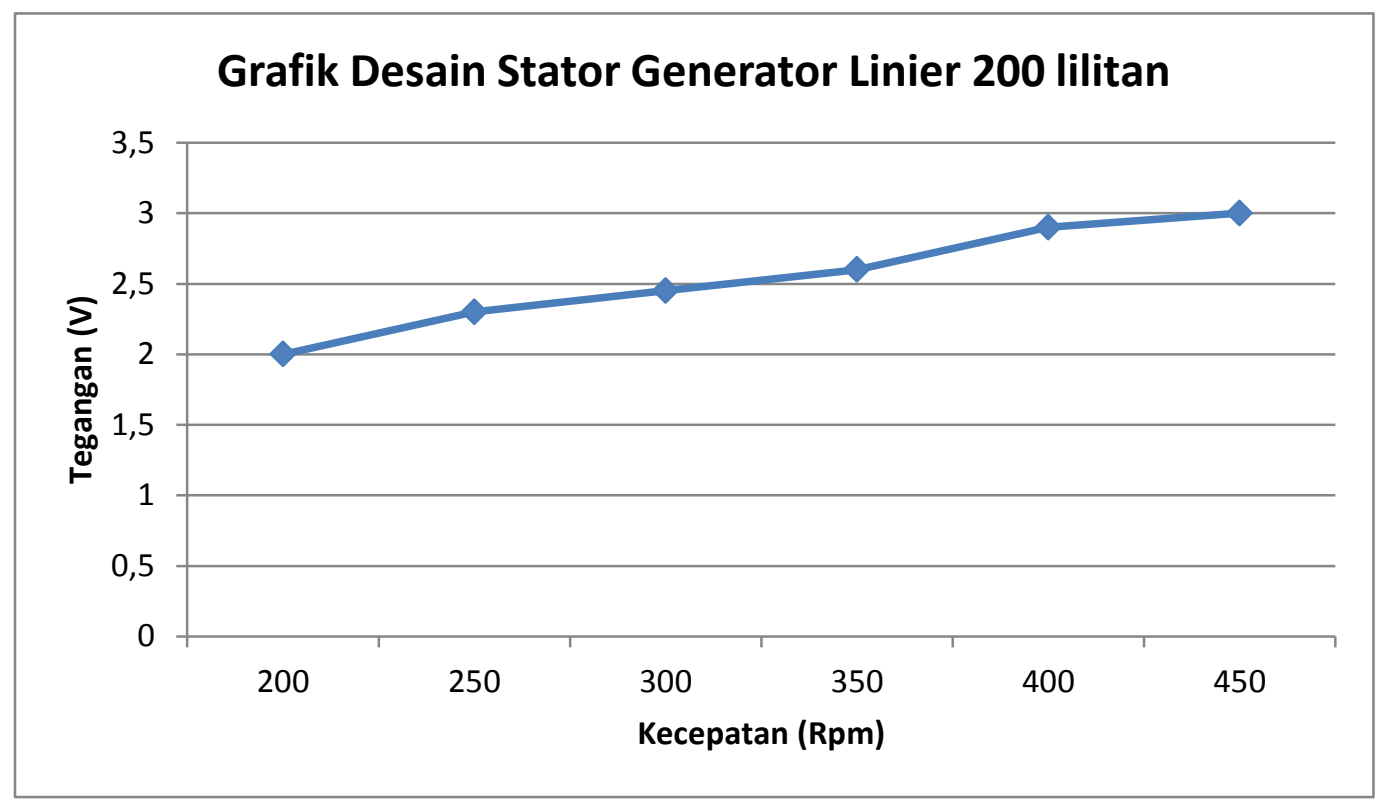

Gambar 13. Grafik Percobaan 3 Tanpa beban

Pada gambar 13 menunjukan peningkatan tegangan keluaran yang terjadi sesuai dengan kecepatan yang di berikan. Pada percobaan yang pertama dan kedua tegangan keluaran tidak mampu melebihi $1 \mathrm{~V}$. Berbeda dengan percobaan ketiga pada kecepatan $200 \mathrm{Rpm}$ dapat menghasilkan keluaran tegangan sebesar

Tabel 1. Percobaan 3, Dengan Beban

\begin{tabular}{llll}
\hline Rpm & Vout & I & Nyala Lampu \\
\hline 200 & $2000 \mathrm{mV}$ & $0,6 \mathrm{~mA}$ & Nyala Redup \\
\hline 250 & $2200 \mathrm{mV}$ & $1,4 \mathrm{~mA}$ & Nyala Redup \\
\hline 300 & $2300 \mathrm{mV}$ & $4,8 \mathrm{~mA}$ & Nyala \\
\hline 350 & $2370 \mathrm{mV}$ & $5,1 \mathrm{~mA}$ & Nyala \\
\hline 400 & $2400 \mathrm{mV}$ & $7 \mathrm{~mA}$ & Nyala Terang \\
\hline 450 & $2470 \mathrm{mV}$ & $8 \mathrm{~mA}$ & Nyala Terang \\
\hline 500 & $2500 \mathrm{mV}$ & $11 \mathrm{~mA}$ & Nyala Terang \\
\hline
\end{tabular}

Pada percobaan ini menggunakan beban berupa 5 buah lampu LED di rangkai secara paralel. Agar arus yang dihasilkan besar. Dilihat dari tabel dan Grafik diatas terjadi peningkatan tegangan maupun arus sesuai dengan kecepatan yang diberikan. Pada kecepatan 200 rpm keluaran sebesar 2000 mV
$2000 \mathrm{mV}$, ketika kecepatan bertambah terjadi peningkatan tegangan keluaran sampai pada kecepatan maksimal $450 \mathrm{rpm}$, menghasilkan tegangan keluaran mencapai $3000 \mathrm{mV}$, ini menunjukan desain ini berhasil dan cocok untuk generator linier. sampai pada kecepatan maksimal $450 \mathrm{rpm}$ menghasilkan tegangan $2500 \mathrm{mV}$. Ada perbedaan antara percobaan tanpa beban dengan menggunakan beban. Perbedaan terjadi pada tegangan yang dikeluarkan oleh desain stator generator linier tersebut. Adanya suatu penurunan nilai tegangan ketika diberi beban. 


\subsection{Analisa Percobaan}

Dari 3 kali percobaan ini dapat dilihat perbedaan yang sangat besar, antara percobaan 1 dan 2 dengan percobaan 3 .

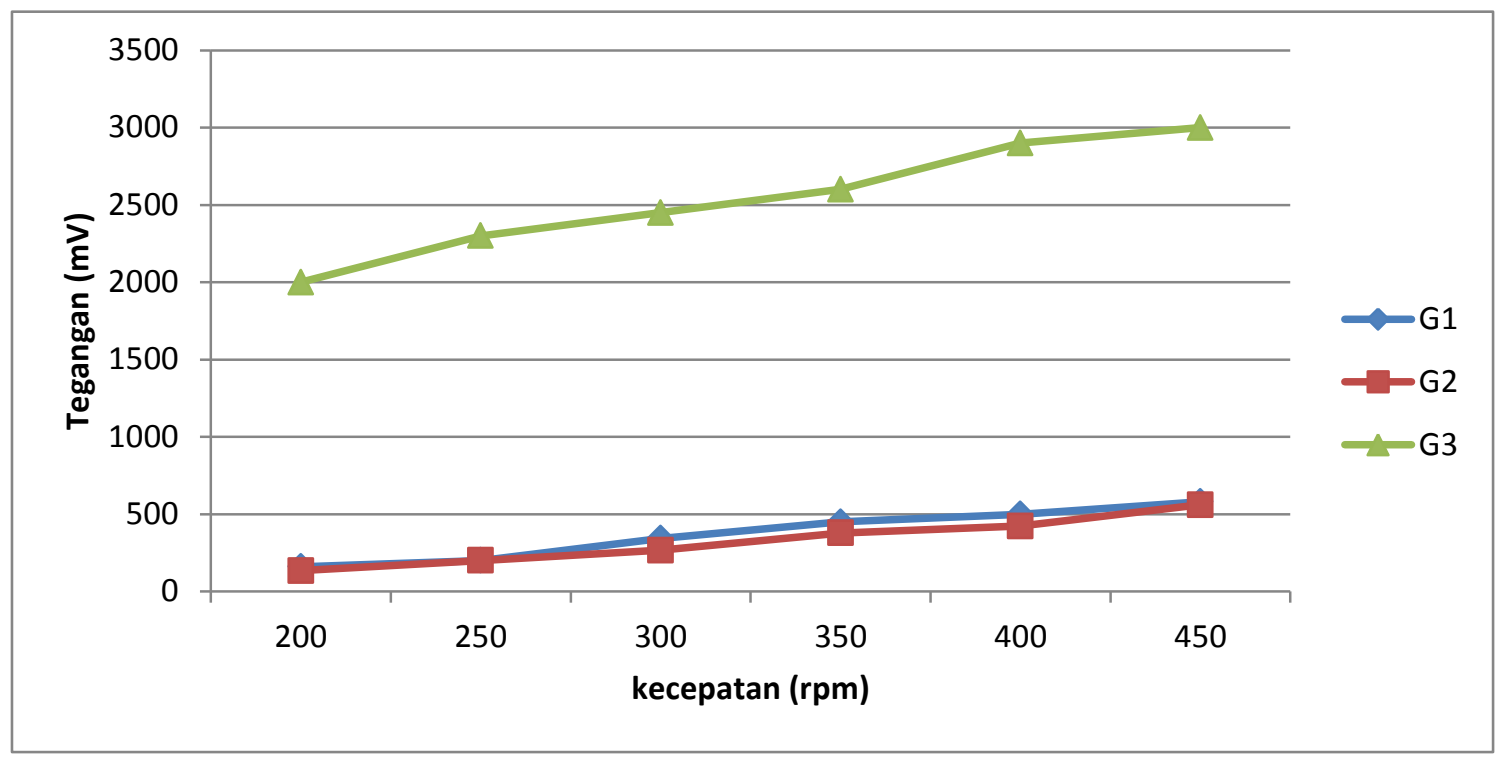

Gambar 14. Grafik tegangan keluaran 3 stator

Pada percobaan 1 dengan kecpatan 200 rpm menghasilkan tegangan keluaran $160 \mathrm{mV}$, terjadi peningkatan tegangan sampai pada 450 rpm menghasilkan tegangan keluaran $580 \mathrm{mV}$. Pada percobaan 2 dengan kecepatan $200 \mathrm{rpm}$ menghasilkan tegangan keluaran $134 \mathrm{mV}$, terjadi peningkatan tegangan keluaran sampai pada 450 rpm menghasilkan $560 \mathrm{mV}$. Kemudian pada percobaan ke 3 terjadi peningkatan yang signifikan, pada kecepatan $200 \mathrm{rpm}$ mampu menghasilkan tegangan 2000 $\mathrm{mV}$, sampai pada kecepatan $450 \mathrm{rpm}$ menghasilkan $3000 \mathrm{mV}$.

Ini membuktikan bahwa percobaan 3 dengan desain stator yang berbeda sangat efektif untuk generator linier, yang bisa menghasilkan tegangan keluaran mencapai 3 volt dengan belitan sebesar 200 lilitan. Bentuk gelombangnya juga stabil, tidak seperti percobaan 1 dan 2 yang bentuk gelombangnya tidak stabil dikarenakan perpotongan medan magnet yang tidak maksimal sehingga mengakibatkan induksi magnetik hilang.

Adapun beberapa kendala pada percobaan desain stator generator linier ini. Saah satunya adalah pada awalnya hasil tegangan yang di keluarkan tidak seperti yang diharapkan. Pada dasarnya desain stator ini dirangkai secara seri, dan ketika diuji kemudian keluaran yang di keluarkan seperti diparalel. Setelah melakukan percobaan berkali kali baru disadari bahwa terjadi kesalahan saat menyambungkan kawat dari wadah belitan ke 1 - wadah belitan ke 6 .

Rangkaian belitan pada generator ini di rangkai secara bolak-balik. Ujung dengan ujung dianggap $\mathrm{A}$ dan $\mathrm{B}$, dan ketika dihubungkan antara kawat $\mathrm{A}$ ke $\mathrm{B}$, kemudian kawat B ke A belitan berikutnya, hasilnya seperti paralel. Padahal secara teori rangkaian tersebut seri. 


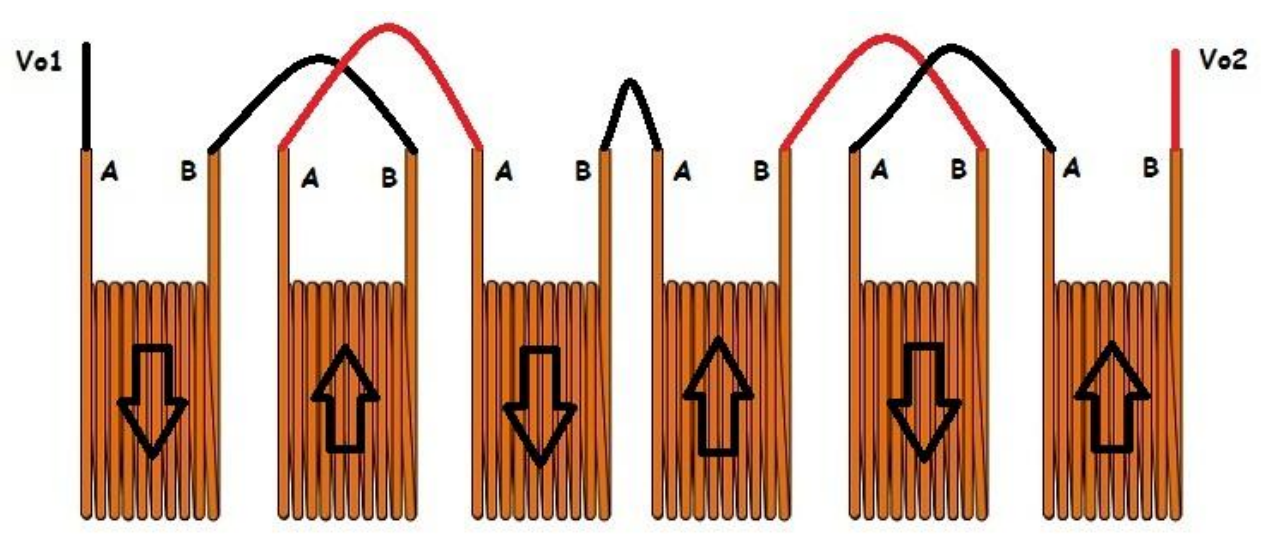

Gambar 15. Rangkaian Sambungan Antar Belitan

Pada gambar 15 menunjukan rangkaian sambungan yang benar sehingga keluaraan tegangan tidak paralel. Keluaran yang dikeluarkan sudah seri seperti yang diharapkan pada penelitian ini.

\section{KESIMPULAN}

Pada dasarnya generator linier mempunyai karakteristik yang sama dengan generator pada umumnya, yang membedakan adalah dari segi desain dan juga gerakan rotornya yang linier. Perpotongan medan magnet sangat penting untuk sebuah generator, sehingga induksi magnetik bisa di hasilkan secara maksimal. Banyak yang mempengaruhi tegangan keluaran dari generator linier antara lain jumlah lilitan, kerapatan/celah udara antara magnet dan juga kualitas kemagnetan dari magnet itu sendiri.

Dari ketiga percobaan, percobaan desain stator ke 3 adalah yang paling efektif untuk generator linier. Dikarenakan perpotongan medan magnet pada percobaan ketiga terjadi secara maksimal, sehingga induksi magnetik terjadi secara terus menerus (tidak hilang). Mampu mengeluarkan tegangan keluaran secara maksimal sebesar 3000 mV.Pada percobaan tanpa beban, dengan Rpm (kecepatan) $200 \mathrm{rpm}$ dapat menghasilkan tegangan $2000 \mathrm{mV}$.

Percobaan stator ke 2 adalah yang paling buruk dari ketiga percobaan. Hanya dapat mengeluakan maksimal teganagan keluaran sebesar $560 \mathrm{mV}$, walaupun sebenarnya hampir sama dengan percobaan 1. Dikarenakan perpotongan medan magnet yang tidak maksimal, sehingga induksi magnetik yang di timbukan kecil dan cederung hilang.

Pada penelitian berikutnya penulis berharap generator linier ini bisa dikembangkan dengan keluaran tegangan yang lebih besar. Dengan menambah jumlah pole (slot lilitan) kemudian merapatkan celah udara, kemudian menambah jumlah lilitan yang semakin banyak dan juga mengubah tipe magnet yang lebih besar kekuatan medan magnetnya, diikuti dengan menambah jumlah magnetnya.

\section{DAFTAR PUSTAKA}

Sharma, Phawan, T.S. Batthi, and K.S.S. Ramarkrishnan. 2011. "PermanentMagnet Induction Generators: An Overview 2 .Classification of PermanentMagnet Machines."Journal of Engineering Science and Technology 6(3): 332-38.

Pawawoi, Andi. 2014. "A New Design of Permanent Magnets Reluctance Generator." 8(2): 461-68.

Park, Sang-shin, Se Myung Park, Jongkyo Jung, and Jin Ho Kim. 2013. "Analysis and Experiments of the Linear Electrical Generator in Wave Energy Farm Utilizing Resonance Power Buoy System 2 .The Linear Electrical Generator for WRPS." 18(3): 250-54.

Rao, Krishna Manasa, and Ashray Gururaja Manur. 2013. "Design Optimization of Linear Generator for a Hydrokinetic Energy Converter." 6(1): 37-40. 